development of types suitable for many parts of the vast territory.

Umanski's discovery that cancer tissue will act as an organizer is very important, and work is proceeding on the study of the conditions necessary for tissue to be capable of being organized. In medical techniques several advances have been made. The transfusion of cadaver blood is a regular procedure now, and it has been found that it is more effective than blood from living donors, although the reason for this is not yet known. The grafting of tissues from corpses was based on the idea that the distinction between life and death and between different organisms is not so fundamental as has been thought. By the use of such processes, Filatov and his assistants have probably restored sight to more people than all other surgeons in the world put together.

Soviet biology is linked not only with agriculture, but also with the development of fishing, hunting, the timber industry, and very closely with medicine. Nevertheless, it does much work of fundamental importance which is altering our theoretical approach to many biological problems.

Mr. J. L. Fyfe made a contribution on the genetics controversy in the U.S.S.R. In his opinion the clash between the geneticists and Lysenko, a physiologist, arose because of the close relation between science and technical needs. Vernalization is the opposite of plant-breeding in the sense that it is designed to produce improved forms of crops by treatment, not to select them by testing. The special importance of vernalization in the Soviet Union is 'its speed as compared with plant-breeding. In 1931 Stalin said that the Soviet Union was fifty or a hundred years behind the advanced countries, and he gave the country ten years to make up leeway. Prejudices have obscured the issues, and this controversy has developed in a period of strong anti-Soviet propaganda. Mr. Fyfe went on to discuss the relation between genetics and the ideas of Lysenko. These ideas are in many ways contradictory to the basic postulates of genetics, but it is significant that recent developments in genetics itself are doing very much the same thing. Genetics is thus approaching a crisis, and the work and ideas of Lysenko are contributing to this developing crisis. The crying need, however, is for careful experimental work to test the theories of Lysenko, for it would be as foolish to set him up as an infallible prophet as it is to dismiss his work lightly.

Mrs. Beatrice King spoke on science in Soviet school education, which, she said, can only be understood in its social and economic setting. In the struggle of an economically backward country to transform itself in a few years into an advanced one through the building of a socialist economy, science has been of prime importance. In education, also, the Soviet Union has passed through a period of intense struggle to become an advanced country and to develop among the people the scientific outlook which is essential for the building of socialism.

In school the approach is historical and international, and science is directly linked with social and economic problems so that children learn at an early stage to think scientifically and not to regard science as a separate subject. All children study scientific subjects experimentally as well as theoretically, but there is no specialization in ordinary schools. The text-books which are used in schools and in universities are generally the work of several writers and are always tried out for a year before being finally approved.

Outside school, science plays a large part in the lives of the children. Science and scientific discoveries bulk largely in the literature of children of all ages, while their plays and films often have scientific subjects. The children's Pioneer Palaces always have laboratories, and school science and exploration clubs flourish, while excursions to the country and to museums and regional-study holidays are attended by millions of children every year.

Dr. M. Ruhemann spoke on the scientific worker in Soviet society. Soviet men of seience have closer contact with other strata of the population than is the case in Western countries, and they react to the pressure of public opinion from a people which has learned to respect science and to expect a lot from it. In most cases students receive a stipend from the State during their five-year course. The best students can proceed to do research work with increased stipends and are entitled to all the help that their seniors can give them. As a member of the same trade union as all other employees in the institution, whether technical, scientific or office workers, the man of science becomes bound up with the life of the institute. The intense Soviet life around, the unlimited scope for solving practical problems, and, finally, the basic Marxist conception of science as the foundation of technique and of the development of the productive forces of society make the scientific worker a conscious and enthusiastic citizen.

The whole symposium was attended by about 250 people, and Marx House is to be congratulated on the organiźation of such a successful set of meetings. These symposia constitute a valuable contribution to Anglo-Soviet unity and understanding.

\section{THE SCIENTIFIC WORK OF ELIE METCHNIKOFF}

\author{
BY DR. G. F. PETRIE \\ Lister Institute
}

\section{$\mathrm{T}$} HE heightened interest in the cultural and intellectual activities of the U.S.S.R. has stimulated a desire to know more about the work of outstanding Russian men of science who belong to the recent past, and thus the anniversary of the birth of Metchnikoff on May 16, 1845, is a fitting time to survey his achievements and to indicate the significance at the present day of his fundamental work on the role of phagocytosis in inflammation and immunity.

Metchnikoff's training as a zoologist was of the greatest value to him throughout his life in guiding his researches, and indeed in consequence of it he was led to the central point of his theory of immunity, for during his stay at Messina in 1882 he made his observations on the mobile cells of a transparent starfish larva and conceived the idea that similar cells might serve to defend the organism against intruding particles whether these were living or non-living. A simple experiment carried out on the spot went far towards establishing the proof. As he himself wrote: "A zoologist until then, I suddenly became a pathologist." During the next twenty-five years the theory was extended by Metchnikoff and his pupils and by numerous workers in many parts of the world to 
include bacterial infections such as anthrax and erysipelas, with the result that ample evidence of the importance of phagocytosis as a means of disposal of intrusive bacterial elements was forthcoming.

Metchnikoff was fortunate in his choice of scientific associates and of the milieu in which his life-work was done. On his first visit to Pasteur in 1887 he was kindly received and was offered a laboratory in the then newly built Institute in the Rue Dutot, whereas, soon afterwards, Koch in Berlin and Emmerich in Munich gave him such a cool reception that he decided to accept Pasteur's offer, and thus in October 1888 he entered the most fruitful period of his career, which lasted until his death in 1916 at the age of seventy-one.

The controversies on the rival doctrines of immunity upheld by the French and the German schools-which, on one side at least, gave the impression of national partisanship-are now of merely historical interest. The humoral theory to which the German workers obstinately clung was based on the direct bactericidal action of the blood-serum of normal and, in particular, of immunized animals. The view now held is that active phagocytosis depends upon sensitization of the bacteria by bacteriotropic substances that are present in normal and immune sera. The two points of view are thus by no means mutually hostile; they are indeed complementary and their relative importance varies with the particular instance of an infective process that is chosen for illustration. After Metchnikoff's death, Aschoff and other workers systematized the cellular theory of immunity by defining the types of cells scattered throughout the tissues and organs of the body that are capable of functioning as phagocytes; these form the so-called reticulo-endothelial system of cells. This scheme of classification has conduced to precision and convenience of description. Recent studies of phagocytosis have been numerous and have been directed towards elucidating the finer mechanisms of the process as revealed by physical and physicochemical methods. The romantic attribution to the phagocytes of purposeful activities as defenders of the citadel of life against bacterial invaders, which so impressed the popular mind in the last decades of the nineteenth century, has given place to more prosaic interpretations. Experimental work has thrown light on such problems as the part played by the nature of the surface of the particles exposed to phagocytosis; the influence of the $p \mathrm{H}$. of the surrounding medium upon the exposed particles and upon the phagocytes; the influence of temperature, of surface forces, and of the viscosity of the cell protoplasm upon the intake of particles; and the differences that are observed in the functional activity of leucocytes when these are collected from healthy and diseased subjects.

Metchnikoff's researches included studies on the comparative pathology of inflammation, a process in which phagocytosis is one of the chief manifestations. His observations on chemotaxis and on intracellular digestion of bacteria engulfed by the phagocytes have not been disturbed by the newer knowledge. There still remains, however, for solution the refractory problem of the deviations from the normal of the biochemical activities within the local phagocytes and fixed tissue cells; these changes must be assumed to vary both in quality and degree throughout the phases of the inflammatory process until the lesion has healed.
The general interest aroused by his work on the transmission of syphilis to chimpanzees and on the prophylaxis of the experimental disease by the inunction of mercurial ointment is still remembered. Metchnikoff had a passion for probing into the mysteries of life and death, as is shown by his own mental reaction to his approaching dissolution, but it would seem that in his views on the production of senile changes in the tissues caused, as he thought, by intoxication from harmful intestinal bacteria, his imaginative powers outran his judgment ; the habit of drinking sour milk as a preventive measure against ill-health and premature old age has now disappeared. Nevertheless, his work has encouraged the important study of the physiology and pathology of senescence, and within recent years this subject has engaged the attention of an enthusiastic group of scientific workers in the United States and also in Great Britain.

Metchnikoff was international in outlook both as a man of science and as a humanist, and here it is worth quoting a sentence from the warmly expressed tribute of Emile Roux, his friend and colleague, on the occasion of Metchnikoff's seventieth birthday. "Resté Russe de nationalité, vous êtes devenu Français par votre choix et vous avez contracté avec l'Institut Pasteur une alliance franco-russe, longtemps avant que les diplomates en aient eu l'idée."

Is it, perhaps, too fanciful to believe that the farreaching speculations of Metchnikoff were influenced by the early impressions which he formed when as a boy he viewed with the eyes of a born naturalist the boundless steppes that surrounded his village home near Kharkoff ? He can never lose his place among the company of the pioneers of experimental medicine.

\section{Dr. B. M. Griffiths}

Dr. B. Mintard Griffrths, who died on March 25, was born at Kidderminster in 1887, and studied at the University of Birmingham during the years 1905-8; he took the D.Sc. degree of that University in 1923. Towards the end of the War of 1914-18 he was assistant to Prof. Yapp at Belfast, but in October of 1920 he was appointed lecturer at Newcastle and afterwards, in 1924, became reader in charge of the new botanical laboratories established at Durham, which he placed upon a secure footing.

His early work concerned the giant bacteria belonging to the genus Hillhousia and was carried out in conjunction with G. T. West, but most of his scientific investigations related to the Algæ. Already in 1912 he published a paper on the Algæ of Stanklin Pool and in 1915 a morphological study of Glaucocystis, while afterwards he turned his attention chiefly to planktonic and limnological studies. We owe to him a considerable number of data on the phytoplankton of the lowland pools of Britain contained in a number of papers published in the Linnean Society's Journal.

He took some part in the foundation of the Freshwater Biological Association and for several years represented the University of Durham on its Council. During the later years of his life he suffered much from ill-health, and this no doubt contributed materially to reduce his output of scientific work, which showed considerable promise.

F. E. Fritsch. 